\title{
Monitoring of methylation changes in 9 p21 region in patients with myelodysplastic syndromes and acute myeloid leukemia
}

\author{
H. CECHOVA*, P. LASSUTHOVA, L. NOVAKOVA, M. BELICKOVA, R. STEMBERKOVA, J. JENCIK, M. STANKOVA, P. HRABAKOVA, K. PEGOVA, \\ H. ZIZKOVA, J. CERMAK
}

Institute of Hematology and Blood Transfusion, U Nemocnice 1, 128 20, Prague, Czech Republic

${ }^{*}$ Correspondence: hana.cechova@uhkt.cz

Received August 9, 2011 / Accepted October 1, 2011

\begin{abstract}
Epigenetic de novo methylation of $\mathrm{CpG}$ islands is an important event in malignant transformation. Two genes are frequently methylated: cyclin-dependent kinase inhibitor $2 \mathrm{~B}(C D K N 2 B)$ and cyclin-dependent kinase inhibitor $2 \mathrm{~A}(C D K N 2 A)$. In our study methylation of these genes was studied in 63 patients with myelodysplastic syndromes (MDS), 2 with myelodysplastic/myeloproliferative neoplasms (MDS/MPN) and 13 with acute myeloid leukemia (AML). Five patients were monitored during 5-azacytidine treatment. Twenty-six healthy donors were tested in a control group. Methylation-specific multiplex ligation-dependent probe amplification (MS-MLPA) method with all associated techniques was used for detection. Aberrant methylation was present in the CDKN2A gene in 38\% and in the CDKN2B gene in 77\% of the patients in MDS group. The level of methylation was higher in the group of AML patients - 77\% in CDKN2A gene and 100\% in CDKN2B gene. In MDS patients, an aberrant methylation was associated with a tendency to disease progression towards more advanced forms according to the World Health Organization (WHO) classification and the International Prognostic Scoring System (IPSS). Significant differences in methylation level were observed between early and advanced forms of MDS in CDKN2B gene $(\mathrm{P}$ value $<0.05)$ but not for CDKN2A gene. The trend of methylation in patients treated with azacitidine was analyzed in $C D K N 2 B$ gene and correlated with the course of the disease. Increased methylation was connected with disease progression. We concluded that the methylation level of $C D K N 2 B$ gene might be used as a marker of leukemic transformation in MDS. Our study indicates the role of hypermethylation as an important event in the progression of MDS to AML.
\end{abstract}

Key words: DNA Methylation, CDKN2A, CDKN2B, 5-azacytidine, MS-MLPA

Epigenetic changes are important events in leukemia patogenesis (1). DNA methylation is one of the most common alterations in leukemia. The potential role of DNA methylation as a biomarker in leukemia has not yet been proven (2). In the human genome, methylated cytosines are found in CpG dinucleotides whose palindromic nature allows for the maintenance of methylation patterns by DNA methyltransferases following semi-conservative replication of DNA. CG-rich regions also known as $\mathrm{CpG}$ islands are located mostly in the promoter regions of genes and are generally unmethylated in healthy tissues $(3,4)$. Their methylation is associated with transcriptional silencing of genes $(5,6,7)$. Methylation changes belong to the most studied epigenetic events in myelodysplastic syndromes (MDS) and acute myeloid leukemia (AML). The most frequently tested genes are CDKN2B gene (cyclin-dependent kinase inhibitor gene, $\mathrm{p} 15^{\mathrm{INK} 4 \mathrm{~B}}$ ) and its functional homologue CDKN2A gene. CDKN2A gene gener- ates several transcript variants which differ in their first exons (isoform 1 called p16 ${ }^{\mathrm{INK} 4 \mathrm{~A}}$ and isoform 4 called p14 $\left.4^{\mathrm{ARF}}\right)(7,8)$. Their function is to regulate cell cycle by inhibition of cyclindependent kinases 4 and 6, which control the progression of cells from G1 to $S$ phase. Hypermethylation of 5 '-CpG islands within the promoter regions was described as an alternative mechanism of CDKN2A/CDKN2B gene inactivation $(7,9)$. An increased hypermethylation of the CDKN2A and CDKN2B promotor regions was found during disease progression and was associated with leukemic transformation and poor prognosis (8).

Myelodysplastic syndromes are a group of clonal hematopoietic disorders. Their pathogenesis is attributed to the important role of an initial damage to hematopoietic stem cells, which ultimately leads to the formation of pathological clone and a growth advantage. This disorder is characterized by pancytopenia due to ineffective hematopoiesis and dyspla- 
sia of hematopoietic cells $(10,11)$. The increased incidence of mutations of oncogenes stimulates proliferation and differentiation of early precursor depressants of hematopoiesis as a consequence of genome instability, leading to a gradual increase in the number of blasts at an advanced stage of disease and the transition into acute myeloid leukemia. Diagnostic criteria have been set up in two classification systems: (the French-American-British [FAB] and the World Health Organization [WHO] ) and in several prognostic-scoring systems, the most widely used being the International Prognostic Scoring System (IPSS) (12). The latest revision of the WHO classification of myeloid neoplasms and acute leukemias was published in $2008(13,14)$.

Treatment with hypomethylating agents and inhibitors of histone deacetylases is an alternative approach to therapy of MDS patients with intermediate-2 or high-risk MDS patients who are not indicated for combination chemotherapy and allogeneic stem cell transplantation (SCT) $(15,16)$. 5-Azacytidine and decitabine are currently available hypomethylating agents $(15,17,18)$. Hypomethylating agents are phosphorylated and incorporated into DNA (as 5-aza-dCTP) during $S$ phase, where they covalently bind to the DNA methyltransferases (DNMTs). They are irreversibly inhibiting their function, leading to the progressive loss of methylation; this process requires that the cell go through S phase (12). Treatment with hypomethylating agents has been shown effective in almost $50 \%$ of treated patients (15).

\section{Patients and methods}

Patients. The methylation status of the CDKN2B and $C D K N 2 A$ genes was studied in DNA samples isolated from bone marrow mononuclear cells (BM)-MNCs from 78 Czech patients ( 39 men and 39 women, median age 59 years; range, 20 - 79 years) with MDS and AML, including 44 cases of refractory cytopenia with multilineage dysplasia (RCMD), 4 cases of refractory cytopenia with multilineage dysplasia and ring sideroblasts (RCMD-RS), 7 cases of refractory anemia with excess blasts-1 (RAEB-1), 8 cases of refractory anemia with excess blasts-2 (RAEB-2), 2 cases of myelodysplastic/ myeloproliferative neoplasms (MDS/MPN) and 13 cases of acute myeloid leukamia (AML). Methylation status was also analyzed in 47 DNA samples extracted from peripherial blood (PB) from 5 patients with demethylation treatment: 1 patient with MDS/MPN and 4 patients with AML treated with 5-azacytidine (Vidaza ${ }^{\circ}$, Celgene Corp., Summit, USA) in the dose of $75 \mathrm{mg} / \mathrm{m}^{2} / \mathrm{d}$ for 7 days every 28 days. Patients with demethylation treatment were monitored continuously during treatment. Twenty-six DNA samples from healthy donors (HD) were used as non-malignant controls. The diagnosis and classification of the MDS were performed according to the WHO 2008 (13). The study was approved by the ethical committee of the Institute of Hematology and Blood Transfusion. All patients and control subjects signed an informed consent to participate in this study.
Table 1. List of methylation specific probes in MLPA kit ME024.

\begin{tabular}{lcc}
\hline Gene & Length $(\mathbf{b p})$ & Chromosomal position \\
\hline$C D K N 2 A$ & 136 & $\mathrm{p} 14^{\mathrm{ARF}}$ promoter \\
$C D K N 2 A$ & 155 & $\mathrm{p} 14^{\mathrm{ARF}}$ promoter \\
$C D K N 2 A$ & 427 & Exon $1\left(\mathrm{p} 14^{\mathrm{ARF}}\right)$ \\
$C D K N 2 B$ & 130 & Exon $1\left(\mathrm{p} 15^{\mathrm{INK} 4 \mathrm{~B}}\right)$ \\
$C D K N 2 B$ & 211 & Exon $1\left(\mathrm{p} 15^{\mathrm{INK} 4 \mathrm{~B}}\right)$ \\
$C D K N 2 B$ & 220 & Exon $1\left(\mathrm{p} 15^{\mathrm{INK} 4 \mathrm{~B}}\right)$ \\
$C D K N 2 B$ & 417 & $\mathrm{p} 15^{\mathrm{INK} 4 \mathrm{~B}}$ promoter \\
$C D K N 2 A$ & 171 & $\mathrm{p} 16^{\mathrm{INK} 4 \mathrm{~A}}$ promoter \\
$C D K N 2 A$ & 237 & Exon $2\left(\mathrm{p} 16^{\mathrm{INK} 4 \mathrm{~A}}\right.$ promoter $)$ \\
\hline
\end{tabular}

Isolation of DNA. Genomic DNA was extracted from bone marrow or peripherial blood mononuclear cells from patients with MDS, AML and controls. Miller's salting out method was used for isolation of DNA (19).

MS-MLPA. Samples were analyzed by MLPA kit (ME024, MRC-Holland, Amsterdam). This MLPA kit provides an easy to perform method for the detection of copy number variations and methylation changes of genes located in

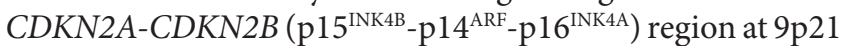
(20). The kit contains 43 different probes -20 probes for the CDKN2A-CDKN2B genes - of which 9 are methylation specific (Table 1), 3 probes for the MTAP gene, 7 probes between MTAP and the 9p telomere region, 2 digestion control probes and 11 reference probes for data analysis. In addition, 9 control fragments are included (http://www.mrc-holland. com) [cit. 11-04-24]). MLPA probes for methylation quantification are similar to normal MLPA probes, except that the sequence detected by the MS-MLPA probe contains the sequence recognized by the methylation-sensitive restriction enzyme HhaI. Extracted genomic DNA (20-200 ng) was used, according to the instructions of the manufacturer (MRC-Holland, Amsterdam, Netherlands). Methylated hybrids of sample DNA were prevented from being digested by $H h a \mathrm{I}$, and then amplified by PCR. Products were analyzed by capillary electrophoresis on an ABI 3500 automatic sequencer (Applied Biosystems, Foster City, CA, USA). If the DNA samples are methylated, proportional peak is visible; on the other hand, if the DNA samples are unmethylated, probes do not generate a signal.

Data and statistical analysis. A MS-MLPA probe targets a single specific HhaI site in a CpG island; if methylation is absent for a particular CpG-site, this does not necessarily mean that the whole $\mathrm{CpG}$ island is unmethylated. Therefore, two approaches are possible while analyzing the results: either to evaluate every single probe or to evaluate the whole gene and average out all probes within this particular gene. We used both methods for data analysis. Data normalization and analysis were performed using the Coffalyser software developed at MRC-Holland (Jordy Coffa, MSc., MRC-Holland, Bio Informatics Research Scientist). Statistical data processing was performed using 


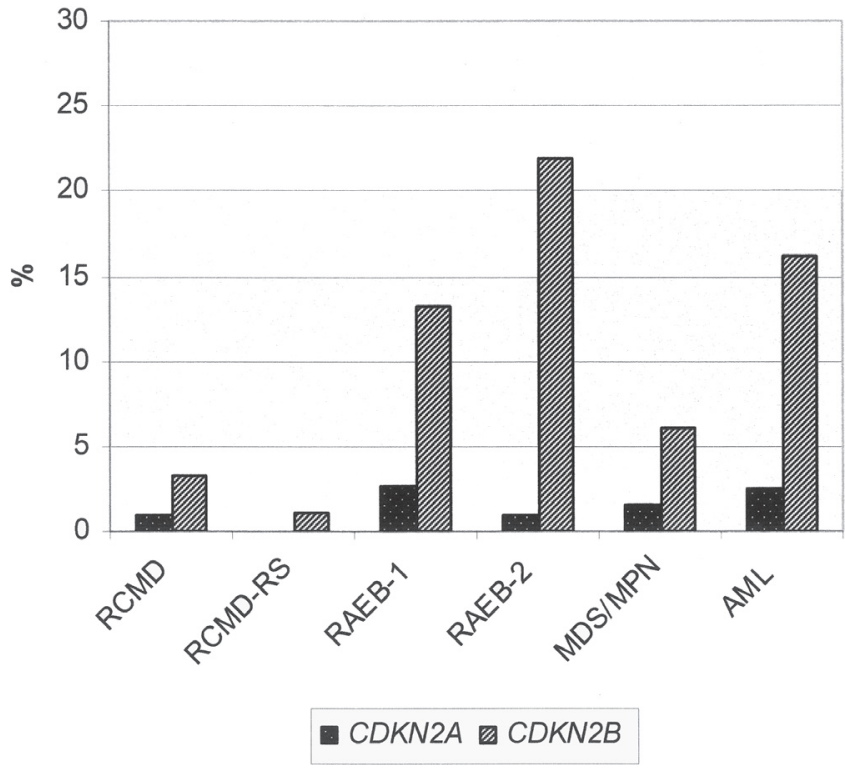

Figure 1. Methylation in each clinical subtype of myelodysplastic syndromes, MDS/MPN and AML for CDKN2A and CDKN2B genes.

The horizontal axis represents subtype and vertical axis the level of methylation in \%.

RCMD, refractory cytopenia with multilineage dysplasia; RCMD-RS, refractory cytopenia with multilineage dysplasia and ring sideroblasts; RAEB-1, refractory anemia with excess blasts-1; RAEB-2, refractory anemia with excess blasts-2; MDS/MPN, myelodysplastic/myeloproliferative neoplasms; AML, acute myeloid leukemia

GraphPad software (GraphPad Software, Inc., La Jolla, CA, USA). Calculations were made with unpaired T-test with Welch's correction.

\section{Results}

Methylation analysis of the CDKN2A and CDKN2B genes. Methylation status of the $C D K N 2 A$ and $C D K N 2 B$ genes was examined in 9p21 regions using MS-MLPA kit in 78 samples obtained from patients with MDS or AML and in 26 samples from healthy donors. Copy number changes were analyzed in all samples. No variations - deletions or duplications - were detected either in patients' samples or in the control group. Nine MS-MLPA probes $(130,136,155$, $157,211,220,237,417$ and $427 \mathrm{bp}$ ) were tested, all of them detect the methylation changes. Based on our experience and literature search we decided to adopt a following approach for data evaluation: average value of methylation of all used probes was used for CDKN2A gene (isoform $1-\mathrm{p} 16^{\mathrm{INK} 4 \mathrm{~A}}$ and isoform $4-\mathrm{p} 14^{\mathrm{ARF}}$, because the values were quite comparable (for p14 ${ }^{\mathrm{ARF}}-136 \mathrm{bp}, 155 \mathrm{bp}$ and $427 \mathrm{bp}$ probes, for $\mathrm{p} 16^{\mathrm{INK} 4 \mathrm{~A}}$ - $171 \mathrm{bp}$ and $237 \mathrm{bp}$ probes). Four probes were included for the CDKN2B gene - $130 \mathrm{bp}, 211 \mathrm{bp}, 220 \mathrm{bp}$ and $417 \mathrm{bp}$ probe. The 211 bp probe was eliminated from the statistical evaluation, because there is a possibility of false positivity if insufficient HhaI activity is present and this probe is incompletely digested, which was also declared by the manufacturer. Methylation of CDKN2B gene was calculated from $130 \mathrm{bp}$, $220 \mathrm{bp}$ and $417 \mathrm{bp}$ probes. The percentages of methylation of genes according to diagnosis or IPSS score are presented in Table 2 and Figure 1 and in Table 3 are levels of methylation of each patient's populations and healthy donors. The results showed 38\% aberrant methylation in the CDKN2A gene and $78 \%$ in the $C D K N 2 B$ gene in patients with MDS and $77 \%$ in $C D K N 2 A$ gene and $100 \%$ in $C D K N 2 B$ gene in the group of patients with AML.

Table 2. Methylation (in \%) of CDKN2A and CDKN2B genes in myelodysplastic syndromes and acute myeloid leukemia according to diagnosis and IPSS score. Brackets indicate the number of methylated/unmethylated cases.

\begin{tabular}{|c|c|c|c|c|}
\hline \multicolumn{2}{|c|}{ according to diagnosis } & \multicolumn{2}{|c|}{ CDKN2A } & \multirow{3}{*}{$\begin{array}{c}\text { CDKN2B } \\
73 \% \\
(32 / 12)\end{array}$} \\
\hline & no. & $\mathrm{p} 14^{\mathrm{ARF}}$ & $\mathrm{p} 16^{\mathrm{INK} 4 \mathrm{~A}}$ & \\
\hline RCMD & 44 & $\begin{array}{c}36 \% \\
(16 / 28)\end{array}$ & $\begin{array}{c}16 \% \\
(7 / 37)\end{array}$ & \\
\hline RCMD-RS & 4 & $\begin{array}{c}0 \% \\
(0 / 4)\end{array}$ & $\begin{array}{c}0 \% \\
(0 / 4)\end{array}$ & $\begin{array}{l}50 \% \\
(2 / 2)\end{array}$ \\
\hline RAEB-1 & 7 & $\begin{array}{l}57 \% \\
(4 / 3)\end{array}$ & $\begin{array}{l}43 \% \\
(3 / 4)\end{array}$ & $\begin{array}{l}100 \% \\
(7 / 0)\end{array}$ \\
\hline RAEB-2 & 8 & $\begin{array}{l}50 \% \\
(4 / 4)\end{array}$ & $\begin{array}{l}13 \% \\
(1 / 7)\end{array}$ & $\begin{array}{c}100 \% \\
(8 / 0)\end{array}$ \\
\hline MDS/MPN & 2 & $\begin{array}{l}50 \% \\
(1 / 1)\end{array}$ & $\begin{array}{c}0 \% \\
(0 / 2)\end{array}$ & $\begin{array}{l}100 \% \\
(2 / 0)\end{array}$ \\
\hline AML & 13 & $\begin{array}{l}62 \% \\
(8 / 5)\end{array}$ & $\begin{array}{l}46 \% \\
(6 / 7)\end{array}$ & $\begin{array}{l}100 \% \\
(13 / 0)\end{array}$ \\
\hline
\end{tabular}

\begin{tabular}{|c|c|c|c|c|}
\hline \multicolumn{2}{|c|}{ according to IPSS score } & \multicolumn{2}{|c|}{ CDKN2A } & \multirow{3}{*}{$\begin{array}{c}\text { CDKN2B } \\
71 \% \\
(10 / 4)\end{array}$} \\
\hline & no. & $\mathrm{p} 14^{\mathrm{ARF}}$ & $\mathrm{p} 16^{\mathrm{INK} 4 \mathrm{~A}}$ & \\
\hline low-risk & 14 & $\begin{array}{c}14 \% \\
(2 / 12)\end{array}$ & $\begin{array}{c}7 \% \\
(1 / 13)\end{array}$ & \\
\hline intermediate-1 & 34 & $\begin{array}{c}41 \% \\
(14 / 20)\end{array}$ & $\begin{array}{c}24 \% \\
(8 / 26)\end{array}$ & $\begin{array}{c}76 \% \\
(26 / 8)\end{array}$ \\
\hline intermediate- 2 & 8 & $\begin{array}{l}63 \% \\
(5 / 3)\end{array}$ & $\begin{array}{l}25 \% \\
(2 / 8)\end{array}$ & $\begin{array}{l}88 \% \\
(7 / 1)\end{array}$ \\
\hline high-risk & 4 & $\begin{array}{l}50 \% \\
(2 / 2)\end{array}$ & $\begin{array}{c}0 \% \\
(0 / 4)\end{array}$ & $\begin{array}{c}100 \% \\
(4 / 0)\end{array}$ \\
\hline
\end{tabular}


Table 3. Representative data of methylation of each patient's populations for different probes and for whole genes. Levels of methylation are in \% (range from 0 to $100 \%) .0 \%$ value is sample without methylation. HD, healthy donors. The isoform p14 ${ }^{\mathrm{ARF}}$ of $C D K N 2 A$ gene included three probes with amplification product at 136,155 and $427 \mathrm{bp}$. The isoform p16 ${ }^{\mathrm{INK} 4 \mathrm{~A}}$ of $C D K N 2 \mathrm{~A}$ gene included two probes with amplification product at 171 and $237 \mathrm{bp}$. $C D K N 2 B$ gene included three probes with amplification product at 130, 220 and $417 \mathrm{bp}$.

\begin{tabular}{|c|c|c|c|c|c|c|c|c|c|c|c|}
\hline & \multicolumn{4}{|c|}{$C D K N 2 A\left(\mathrm{p} 14^{\mathrm{ARF}}\right)$} & \multicolumn{4}{|c|}{$C D K N 2 B\left(p 15^{I N K 4 B}\right)$} & \multicolumn{3}{|c|}{$C D K N 2 A\left(\mathrm{p} 16^{\mathrm{IKN} 4 \mathrm{~A}}\right)$} \\
\hline & 136 bp & $155 \mathrm{bp}$ & 427 bp & total & $130 \mathrm{bp}$ & $220 \mathrm{bp}$ & $417 \mathrm{bp}$ & total & $171 b p$ & $237 \mathrm{bp}$ & total \\
\hline RCMD & $2.6 \%$ & $0.7 \%$ & $0.1 \%$ & $1.2 \%$ & $6.9 \%$ & $3.7 \%$ & $3.8 \%$ & $4.8 \%$ & $0.8 \%$ & $1.2 \%$ & $1.0 \%$ \\
\hline RCMD-RS & $0.0 \%$ & $0.0 \%$ & $0.0 \%$ & $0.0 \%$ & $2.8 \%$ & $0.0 \%$ & $0.0 \%$ & $0.9 \%$ & $0.0 \%$ & $0.0 \%$ & $0.0 \%$ \\
\hline RAEB-1 & $4.7 \%$ & $0.4 \%$ & $1.9 \%$ & $2.3 \%$ & $27.7 \%$ & $17.4 \%$ & $6.4 \%$ & $17.2 \%$ & $1.9 \%$ & $6.4 \%$ & $4.1 \%$ \\
\hline RAEB-2 & $3.9 \%$ & $0.0 \%$ & $0.0 \%$ & $1.3 \%$ & $31.4 \%$ & $17.3 \%$ & $30.1 \%$ & $26.3 \%$ & $0.0 \%$ & $1.9 \%$ & $0.9 \%$ \\
\hline MDS/MPN & $4.3 \%$ & $0.2 \%$ & $0.9 \%$ & $1.8 \%$ & $16.0 \%$ & $0.0 \%$ & $9.0 \%$ & $8.3 \%$ & $0.0 \%$ & $0.0 \%$ & $0.0 \%$ \\
\hline AML & $3.7 \%$ & $2.3 \%$ & $1.7 \%$ & $2.6 \%$ & $26.0 \%$ & $13.5 \%$ & $20.5 \%$ & $20.0 \%$ & $2.3 \%$ & $4.5 \%$ & $3.4 \%$ \\
\hline Low-risk & $1.5 \%$ & $0.5 \%$ & $0.0 \%$ & $0.7 \%$ & $3.3 \%$ & $2.4 \%$ & $2.1 \%$ & $2.6 \%$ & $0.0 \%$ & $0.7 \%$ & $0.4 \%$ \\
\hline Intermediate-1 & $2.7 \%$ & $0.8 \%$ & $0.2 \%$ & $1.2 \%$ & $8.1 \%$ & $6.1 \%$ & $3.7 \%$ & $6.0 \%$ & $1.1 \%$ & $1.3 \%$ & $1.2 \%$ \\
\hline Intermediate-2 & $3.5 \%$ & $0.7 \%$ & $0.8 \%$ & $1.6 \%$ & $23.7 \%$ & $18.5 \%$ & $19.6 \%$ & $20.6 \%$ & $0.9 \%$ & $2.5 \%$ & $1.7 \%$ \\
\hline High-risk & $2.5 \%$ & $0.7 \%$ & $0.3 \%$ & $1.2 \%$ & $14.9 \%$ & $8.3 \%$ & $21.4 \%$ & $14.8 \%$ & $0.0 \%$ & $0.0 \%$ & $0.0 \%$ \\
\hline HD & $1.1 \%$ & $0.0 \%$ & $0.0 \%$ & $0.4 \%$ & $3.2 \%$ & $0.0 \%$ & $1.8 \%$ & $1.7 \%$ & $0.0 \%$ & $3.6 \%$ & $1.8 \%$ \\
\hline
\end{tabular}

Statistical comparisons between different subtypes of MDS, AML and IPSS groups were made for each single probe and also for the gene in 9p21 region. $\mathrm{P}$ values for the genes are shown in Table 4.

Methylation analysis of the CDKN2B gene in five patients treated with 5-azacytidine (Vidaza). We analyzed methylation status in 47 samples from five patients during the hypomethylation treatment - four patients with AML and one patient with MDS/MPN. The trend of methylation status was monitored in CDKN2B gene, especially in the 130 bp probe (probe 11867-L12664, the coding region of exon 1). On the basis of a previous analysis of 78 patients this probe was capable of corresponding with disease progression.

The trend of methylation changes in individual patients and the correlation with the disease progression or remission of the disease is described in detail in legend of Figure 2. The methylation changes were only subtle, in the range of $1-5$ percent. The correlation of disease progression was particularly shown in patients $\mathrm{P} 1$ and $\mathrm{P} 3$, where the level of methylation had increased by $11 \%$ after 11 th cycle of the treatment in patient $\mathrm{P} 1$ and by $6 \%$ after 9 th cycle of treatment in patient P3.

\section{Discussion}

Silencing of proliferation-associated genes by aberrant hypermethylation is often found in neoplasia. In the present study we have shown that hypermethylation is an important event in the progression of MDS to AML. Two issues were addressed. Firstly, the intensity of methylation of CDKN2A$C D K N 2 B$ genes in different subtypes of MDS according to WHO classification and IPSS score has been studied. Secondly,
Table 4. Statistical comparison in 3 different groups for CDKN2A and CDKN2B genes.

Unpaired T-test with Welch's correction was used for statistical comparison.

Early versus Advanced MDS (RCMD, RCMR-RS x RAEB-1, RAEB-2)

\begin{tabular}{|c|c|c|c|}
\hline \multirow{3}{*}{$C D K N 2 A$} & & P value & Statistical significance $(\mathrm{P}<0.05)$ \\
\hline & p14 ${ }^{\mathrm{ARF}}$ & 0.3051 & No \\
\hline & p16 $^{\mathrm{INK} 4 \mathrm{~A}}$ & 0.1909 & No \\
\hline CDKN2B & p15 $5^{\mathrm{INK} 4 \mathrm{~B}}$ & $<0.0001$ & Yes \\
\hline \multicolumn{4}{|c|}{ Low-risk + Intermediate-1 versus Intermediate-2 + High-risk } \\
\hline \multirow{3}{*}{ CDKN2A } & & P value & Statistical significance $(\mathrm{P}<\mathbf{0 . 0 5})$ \\
\hline & p14 ${ }^{\mathrm{ARF}}$ & 0.3935 & No \\
\hline & $\mathrm{p}^{16^{\mathrm{INK} 4 \mathrm{~A}}}$ & 0.5454 & No \\
\hline CDKN2B & p15 $5^{\mathrm{INK} 4 \mathrm{~B}}$ & 0.003 & Yes \\
\hline \multicolumn{4}{|c|}{ MDS versus AML } \\
\hline \multirow{3}{*}{$C D K N 2 A$} & & P value & Statistical significance $(\mathrm{P}<0.05)$ \\
\hline & p14 ${ }^{\mathrm{ARF}}$ & 0.1031 & No \\
\hline & $\mathrm{p}^{16} \mathrm{INK}^{\mathrm{INA}}$ & 0.0935 & No \\
\hline$C D K N 2 B$ & p15 ${ }^{\mathrm{INK} 4 \mathrm{~B}}$ & 0.0014 & Yes \\
\hline
\end{tabular}

the response of patients to the treatment with hypomethylation agents was evaluated.

We analyzed the intensity of methylation of CDKN2A and $C D K N 2 B$ genes according to diagnosis and IPSS score. All the results were compared with the results obtained from healthy controls. The sample was considered as unmethylated, if all the probes for the gene were without methylation. Aberrant methylation was detected in 38\% in CDKN2A gene and in $78 \%$ in $C D K N 2 B$ gene in patients with MDS according to 

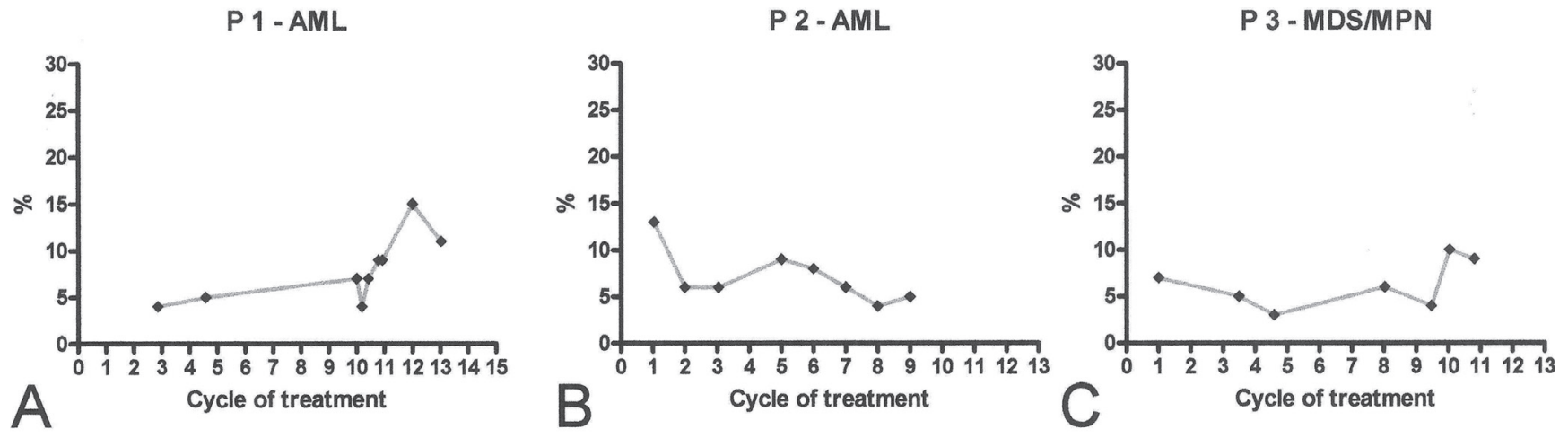

P 4 - AML

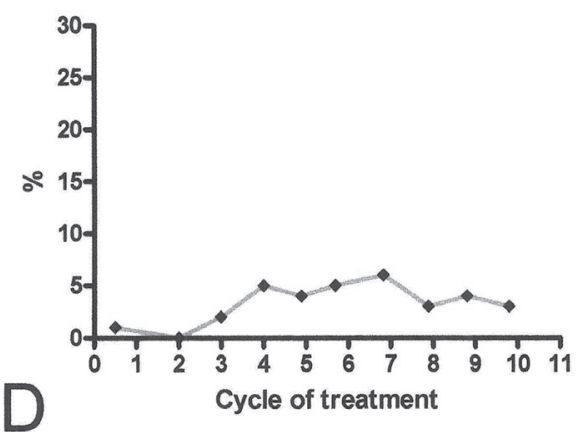

P 5 - AML

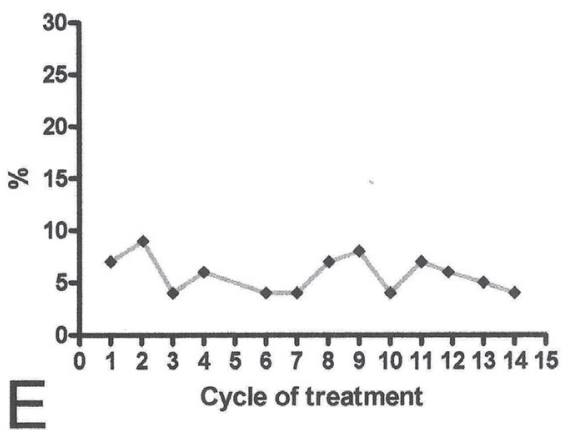

Figure 2. Monitoring of methylation in $C D K N 2 B$ in five patients treated with 5-azacytidine.

The horizontal line represents cycles of treatment with 5-azacytidine and the vertical line represents the intensity of methylation. (A) The patient with AML achieved stable disease during the treatment with 5-azacytidine, new progression of the disease was observed after cycle 11 of the treatment. (B) Patient with AML achieved partial remission and the treatment is continuing. (C) Patient with MDS/MPN was treated because of new disease progression after allogeneic SCT, but progression of the disease was observed during the treatment after cycle 9. (D) Patient with AML achieved partial remission of the disease. (E) Patient with AML achieved stable disease but relapsed after cycle 14.

diagnosis. Hypermethylation was observed in AML patients ( $77 \%$ in CDKN2A gene and $100 \%$ in CDKN2B gene). The majority of other studies has focused on the detection of aberrant methylation in $C D K N 2 B$ gene, only a few have analyzed also $C D K N 2 A$ gene. Reports from other authors have shown aberrant methylation of $C D K N 2 B$ gene of $50-80 \%$ on average in AML patients (2,21). Agrawal et al. (2007) detected CDKN2B methylation in $60 \%$ (2) and Herman et al. (1997) in $88 \%$ of AML patiens (21). Furthermore, there are also reports from other authors who showed that the value of methylation of $C D K N 2 B$ gene was in the range of $40-60 \%$ in MDS patients $(7,8,11,22)$. Aggerholm et al. (2006) found methylation of CDKN2B gene in $51 \%$ of MDS patients (22). Our results are slightly different, the percentage of methylation being higher. This is probably due to the fact that the MS-MLPA method that we have used, and the very kit ME-024, contains 43 probes selectively for $C D K N 2 A$ and $2 B$ gene regions. Solomon et al. (2008) detected methylation in $61 \%$ in CDKN2B gene and in $37 \%$ in CDKN2A (p16 ${ }^{\mathrm{INK4A}}$ ) gene of MDS patients. They used a method of semi-nested multiplex PCR and primers located in the CpG rich islands of the promoter at least 500 bp upstream of the transcription start site, enclosing at least one HpaII restriction site (8). The examined group of patients was smaller than our one; however, the results obtained in this study were very similar to our results. Uchida et al. (1997) showed that no apparent hypermethylation of CDKN2A $\left(\mathrm{p} 16^{\mathrm{INK} 4 \mathrm{~A}}\right)$ gene was detected in patients with MDS (11) while in our study we detected methylation in $38 \%$ of MDS patients. This could be caused by the different design of primers used in these two studies. Our methylation probes were designed to detect methylation in regions located nearer the gene of interest while Uchida used primers located in a different region of interest.

The level of methylation was increasing in accordance with IPSS score (from low-risk to intermediate-2-risk patients), except for the high-risk group. In this group the level of methylation was $14.8 \%$ in CDKN2B gene, however, in the intermediate-2-risk group the level was $20.6 \%$. This result is most likely due to the small number of patients (only four) in the high-risk group and this could be the source of bias. Other studies detected an increase of methylation intensity continu- 
ally from low-risk to high-risk $(7,11)$ and we suppose that we would observe the same trend if more patients had been included. These results support our current understanding of the mechanism of methylation and its role in neoplasia, as it was proposed by Herman et al. $(1996,1997)$ who showed that aberrant DNA methylation is associated with inactivation of tumor suppressor gene $\left(\mathrm{p} 15^{\mathrm{INK} 4 \mathrm{~B}}, \mathrm{p} 16^{\mathrm{INK} 4 \mathrm{~A}}\right)(21,23)$ and therefore with disease progression.

Vasikova et al. (2010) compared gene expression profiles of CD34+ cells of MDS patients and healthy controls using HumanRef- 8 v2 Expresion Bead Chips from Illumina. They observed expression differences between patients and controls. The expression of genes involved in cell cycle and DNA repair was significantly lower in advanced MDS patients, what might indicate altered and inappropriate reaction of the cell towards mutagenic agents during the disease progression. On the other hand, the level of expression of protooncogenes, angiogenic, anti-apoptic genes and genes of signal transduction was increased. They have concluded, that overexpression of these genes might be important for a malignant clone expansion in MDS patients (24). Twenty-two of our patients were included in their study. The link between our study and the study of Vasikova et al. (2010) is that level of methylation and expression of several transcription factors is closely related. The level of methylation, which was detected in our study, showed increasing trend in our patients (at RCMD 4.8\%, at RAEB-1 17.2\% and RAEB-2 26.3\%). Concurrently, there was detected firm adherence in trend of downregulation of transcription factors E2F1 and E2F2 from the early to advanced forms of MDS (at RCMD -1.1x, at RAEB-1 -1.7x and RAEB-2 $-2.4 \mathrm{x}$ than healthy controls).

Our study focused on monitoring the intensity of methylation in patients treated with the hypomethylation agent 5 -azacytidine. Based on the results of our previous analysis of seventy-eight samples, we decided to monitor the methylation status only in the CDKN2B gene, especially in 130 bp probe. This probe is located in exon 1a, whose HhaI site is located 33 base pairs before the first methionine. Other probes coding for $C D K N 2 B$ gene are the 220 bp probe, whose HhaI site is located 100 base pairs before the first methionine, or the $417 \mathrm{bp}$ probe located $155 \mathrm{bp}$ before the exon 1a. The most consistent results were obtained for the $130 \mathrm{bp}$ probe and we speculate that this probe might be located in an important area, the closest to the coding region of the $C D K N 2 B$ gene. We suppose that this region might play an important role in the regulation of the $C D K N 2 B$ gene. However, further experiments are needed.

In the group of patients treated with 5-azacytidine, the trend of methylation partly correlated with disease progression, but the methylation changes were only subtle. In our study, two from five patients achieved partial remission while the three remaining patients progressed. The results of other studies are fairly consistent, showing about $40 \%$ of patients responding to treatment with hypomethylating agents $(25,26)$.

Allogeneic SCT is the only treatment modality in MDS, but is available only for selected patients depending mainly on the amount of the bone marrow blasts, comorbidities, suitable donor and other criteria $(15,18)$. For patients who are not indicated for combination therapy and allogeneic SCT or do not have a suitable donor for SCT, 5-azacytidine represents a new treatment option. Results from the literature show that treatment with 5-azacytidine may be effective in patients with intermediate- 2 and high-risk MDS because of prolongation of overall survival $(15,18,27)$. 5-Azacytidine has been observed to produce better responses in patients with unfavourable cytogenetics and was effective in reducing the risk of disease relapse or in the treatment AML relapse after allogeneic SCT $(15,18,28,29)$. There are also reports supporting the feasibility and effectiveness of 5-azacytidine treatment in patients with lower-risk MDS (16). 5-Azacytidine has been also used as a first line treatment in patients with de novo acute myeloid leukemia similarly as several patients in our cohort.

In summary, aberrant methylation in the $\mathrm{CpG}$ islands was present frequently in the CDKN2B gene and increase of methylation was accompanied by disease progression. Thus, the methylation level of this gene might be used as a marker of leukemic transformation in MDS (1). Our study indicates an important role of hypermethylation in the progression of MDS to AML.

Acknowledgments: We thank patients from the Institute of Hematology and Blood Transfusion for their participation, their attending physicians and Bohumir Prochazka for statistical analyses. This study was supported by the grant of MHCR 00023736.

\section{References}

[1] ISSA JP, KANTARJIAN HM. Targeting DNA methylation. Clin Cancer Res. 2009 Jun 15; 15(12): 3938-46. http://dx.doi. org/10.1158/1078-0432.CCR-08-2783

[2] AGRAWAL S, UNTERBERG M, KOSCHMIEDER S, ZUR STADT U, BRUNNBERG U et al. DNA methylation of tumor suppressor genes in clinical remission predicts the relapse risk in acute myeloid leukemia. Cancer Res. 2007 Feb 1; 67(3): 1370-7. http://dx.doi.org/10.1158/0008-5472.CAN-06-1681

[3] CAIAFA P, ZAMPIERI M. DNA methylation and chromatin structure: the puzzling CpG islands. J Cell Biochem. 2005 Feb 1; 94(2): 257-65. Review. http://dx.doi.org/10.1002/ jcb. 20325

[4] HERMAN JG, GRAFF JR, MYÖHÄNEN S, NELKIN BD, BAYLIN SB. Methylation-specific PCR: a novel PCR assay for methylation status of CpG islands. Proc Natl Acad Sci U S A. 1996 Sep 3; 93(18): 9821-6.

[5] ESTELLER M, HERMAN JG. Cancer as an epigenetic disease: DNA methylation and chromatin alterations in human tumours. J Pathol. 2002 Jan; 196(1): 1-7. Review. http://dx.doi. org/10.1002/path.1024

[6] MERLO A, HERMAN JG, MAO L, LEE DJ, GABRIELSON E et al. 5' CpG island methylation is associated with transcriptional silencing of the tumour suppressor p16/CDKN2/MTS1 in human cancers. Nat Med. 1995 Jul; 1(7): 686-92. http:// dx.doi.org/10.1038/nm0795-686 
[7] TIEN HF, TANG JH, TSAY W, LIU MC, LEE FY et al. Methylation of the p15(INK4B) gene in myelodysplastic syndrome: it can be detected early at diagnosis or during disease progression and is highly associated with leukaemic transformation. Br J Haematol. 2001 Jan; 112(1): 148-54. http://dx.doi. org/10.1046/j.1365-2141.2001.02496.x

[8] SOLOMON PR, MUNIRAJAN AK, TSUCHIDA N, MUTHUKUMARASAMY K, RATHINAVEL A et al. Promoter hypermethylation analysis in myelodysplastic syndromes: diagnostic \& prognostic implication. Indian J Med Res. 2008 Jan; 127(1): 52-7.

[9] CHRISTMAN JK. 5-Azacytidine and 5-aza-2'-deoxycytidine as inhibitors of DNA methylation: mechanistic studies and their implications for cancer therapy. Oncogene. 2002 Aug 12; 21(35): 5483-95. Review. http://dx.doi.org/10.1038/ sj.onc. 1205699

[10] MALCOVATI L, NIMER SD. Myelodysplastic syndromes: diagnosis and staging. Cancer Control. 2008 Oct;15 Suppl:413. Review.

[11] UCHIDA T, KINOSHITA T, NAGAI H, NAKAHARA Y, SAITO $\mathrm{H}$ et al. Hypermethylation of the p15INK4B gene in myelodysplastic syndromes. Blood. 1997 Aug 15; 90(4): 1403 9.

[12] NIMER SD. Myelodysplastic syndromes. Blood. 2008 May 15; 111(10): 4841-51. Review. http://dx.doi.org/10.1182/blood2007-08-078139

[13] VARDIMAN JW, THIELE J, ARBER DA, BRUNNING RD, BOROWITZ MJ et al. The 2008 revision of the World Health Organization (WHO) classification of myeloid neoplasms and acute leukemia: rationale and important changes. Blood. 2009 Jul 30; 114(5): 937-51. http://dx.doi.org/10.1182/blood-200903-209262

[14] WEINBERG OK, SEETHARAM M, REN L, SEO K, MA L et al. Clinical characterization of acute myeloid leukemia with myelodysplasia-related changes as defined by the 2008 WHO classification system. Blood. 2009 Feb 26; 113(9): 1906-8. http://dx.doi.org/10.1182/blood-2008-10-182782

[15] FENAUX P, MUFTI GJ, HELLSTROM-LINDBERG E, SANTINI V, FINELLI C et al. Efficacy of azacitidine compared with that of conventional care regimens in the treatment of higher-risk myelodysplastic syndromes: a randomised, openlabel, phase III study. Lancet Oncol. 2009 Mar; 10(3): 223-32. http://dx.doi.org/10.1016/S1470-2045(09)70003-8

[16] SANTINI V. Azacitidine in lower-risk myelodysplastic syndromes. Leuk Res. 2009 Dec;33 Suppl 2: S22-6. http://dx.doi. org/10.1016/S0145-2126(09)70230-9

[17] TEFFERI A.Myelodysplastic syndromes--many new drugs, little therapeutic progress. Mayo Clin Proc. 2010 Nov;85(11):10425. http://dx.doi.org/10.4065/mcp.2010.0502

[18] VIGIL CE, MARTIN-SANTOS T, GARCIA-MANERO G. Safety and efficacy of azacitidine in myelodysplastic syndromes. Drug Des Devel Ther. 2010 Sep 24; 4: 221-9. Review.
[19] MILLER SA, DYKES DD, POLESKY HF. A simple salting out procedure for extracting DNA from human nucleated cells. Nucleic Acids Res. 1988 Feb 11; 16(3): 1215. http://dx.doi. org/10.1093/nar/16.3.1215

[20] NYGREN AO, AMEZIANE N, DUARTE HM, VIJZELAAR RN, WAISFISZ Q et al. Methylation-specific MLPA (MSMLPA): simultaneous detection of CpG methylation and copy number changes of up to 40 sequences. Nucleic Acids Res. 2005 Aug 16; 33(14): e128. http://dx.doi.org/10.1093/nar/ gni127

[21] HERMAN JG, CIVIN CI, ISSA JP, COLLECTOR MI, SHARKIS SJ et al. Distinct patterns of inactivation of p15INK4B and p16INK4A characterize the major types of hematological malignancies. Cancer Res. 1997 Mar 1; 57(5): 837-41.

[22] AGGERHOLM A, HOLM MS, GULDBERG P, OLESEN LH, HOKLAND P. Promoter hypermethylation of p15INK4B, $\mathrm{HIC1}, \mathrm{CDH} 1$, and ER is frequent in myelodysplastic syndrome and predicts poor prognosis in early-stage patients. Eur J Haematol. 2006 Jan; 76(1): 23-32. http://dx.doi.org/10.1111/ j.1600-0609.2005.00559.x

[23] HERMAN JG, JEN J, MERLO A, BAYLIN SB. Hypermethylation-associated inactivation indicates a tumor suppressor role for p15INK4B. Cancer Res. 1996 Feb 15; 56(4): 722-7.

[24] VASIKOVA A, BELICKOVA M, BUDINSKA E, CERMAK J. A distinct expression of various gene subsets in CD34+ cells from patients with early and advanced myelodysplastic syndrome. Leuk Res. 2010 Dec; 34(12): 1566-1572. http://dx.doi. org/10.1016/j.leukres.2010.02.021

[25] FANDY TE, HERMAN JG, KERNS P, JIEMJIT A, SUGAR EA et al. Early epigenetic changes and DNA damage do not predict clinical response in an overlapping schedule of 5-azacytidine and entinostat in patients with myeloid malignancies. Blood. 2009 Sep 24; 114(13): 2764-73.

[26] RAJ K, JOHN A, HO A, CHRONIS C, KHAN S et al. CDKN2B methylation status and isolated chromosome 7 abnormalities predict responses to treatment with 5-azacytidine. Leukemia. 2007 Sep; 21(9): 1937-44. http://dx.doi. org/10.1038/sj.leu.2404796

[27] TRAN HT, KIM HN, LEE IK, KIM YK, AHN JS et al. DNA methylation changes following 5-azacitidine treatment in patients with myelodysplastic syndrome. J Korean Med Sci. 2011 Feb; 26(2): 207-13. http://dx.doi.org/10.3346/ jkms.2011.26.2.207

[28] GRAEF T, KUENDGEN A, FENK R, ZOHREN F, HAAS R et al. Successful treatment of relapsed AML after allogeneic stem cell transplantation with azacitidine. Leuk Res. 2007 Feb; 31(2): 257-9. http://dx.doi.org/10.1016/j.leukres.2006.03.003

[29] JABBOUR E, GIRALT S, KANTARJIAN H, GARCIA-MANERO G, JAGASIA M et al. Low-dose azacitidine after allogeneic stem cell transplantation for acute leukemia. Cancer. 2009 May 1; 115(9): 1899-905. http://dx.doi.org/10.1002/cncr.24198 